\title{
IN-DEPTH SURVEY REPORT OF A LOCAL EXHAUST VENTILATION DEVICE FOR SUPPRESSING RESPIRABLE AND CRYSTALLINE SILICA DUST FROM POWERED SAWS
}

\author{
At \\ Revelation Roofing \\ Denver, CO \\ REPORT WRITTEN BY: \\ Alberto Garcia, MS \\ Erica Jones, MS \\ Alan Echt, MPH, CIH \\ Ron Hall, CIH, MS \\ REPORT DATE: \\ May, 2006 \\ REPORT NO: \\ EPHB 317-12a
}

U.S. DEPARTMENT OF HEALTH AND HUMAN SERVICES

Centers for Disease Control and Prevention

National Institute for Occupational Safety and Health

Division of Applied Research and Technology

Engineering and Physical Hazards Branch

4676 Columbia Parkway, Mail Stop R-5

Cincinnati, Ohio 45226-1998 

SITES SURVEYED:

SIC CODE:

SURVEY DATE:

SURVEY CONDUCTED BY:

EMPLOYER REPRESENTATIVE CONTACTED:

EMPLOYEE REPRESENTATIVE CONTACTED:
Revelation Roofing Denver, CO

1761

July 26-28, 2005

Alan Echt, NIOSH

Alberto Garcia, NIOSH

Erica Jones, NIOSH

Ron Hall, NIOSH

Steve Bures

Revelation Roofing, Inc.

NONE 


\section{DISCLAIMER}

Mention of company names or products does not constitute endorsement by the Centers for Disease Control and Prevention.

The findings and conclusions in this report are those of the authors and do not necessarily represent the views of the National Institute for Occupational Safety and Health. 


\begin{abstract}
The objective of this study was to quantify the respirable dust and respirable silica exposures of roofing workers using an electric powered saw with an aftermarket local exhaust ventilation attachment. The study was conducted to determine whether the local exhaust ventilation attachment was able to control respirable dust and respirable silica exposure below occupational exposure limits. Sampling was conducted at three different sites near Denver, CO. Timeintegrated filter samples and direct reading respirable dust concentrations were evaluated.

Respirable dust from the trials ranged from 0.13 to $6.59 \mathrm{mg} / \mathrm{m}^{3}$ with an average of $0.84 \mathrm{mg} / \mathrm{m}^{3}$ for roofers and from 0.45 to $3.82 \mathrm{mg} / \mathrm{m}^{3}$ with an average of $2.01 \mathrm{mg} / \mathrm{m}^{3}$ for cutters $/$ roofers. The respirable dust exposures for all cutters/roofers indicated concentrations exceeding the OSHA PEL; it was also exceeded for some of the roofers. The respirable silica concentrations ranged from 0.04 to $0.15 \mathrm{mg} / \mathrm{m}^{3}$ with an average of $0.09 \mathrm{mg} / \mathrm{m}^{3}$ for roofers, and from 0.13 to 1.21 $\mathrm{mg} / \mathrm{m}^{3}$ with an average of $0.48 \mathrm{mg} / \mathrm{m}^{3}$ for cutters/roofers. As with respirable dust, the respirable silica exposures to cutters/roofers were higher than the exposures for roofers.

In general, higher respirable dust and respirable silica exposures were observed for the saw operators than for other roofers. However, all workers were overexposed to respirable dust and respirable silica for at least one monitored shift. The use of the engineering control alone is not sufficient for reducing exposures below acceptable occupational exposure levels. Redesign options for the control should be considered. In the meantime, work practice modifications, administrative controls, and a comprehensive respiratory protection program should be implemented in order to control respirable dust and respirable silica exposures.
\end{abstract}




\section{INTRODUCTION}

The National Institute for Occupational Safety and Health (NIOSH) is located in the Centers for Disease Control and Prevention (CDC), part of the Department of Health and Human Services (DHHS). NIOSH was established in 1970 by the Occupational Safety and Health Act, at the same time that the Occupational Safety and Health Administration (OSHA) was established in the Department of Labor (DOL). The OSH Act legislation mandated NIOSH to conduct research and education programs separate from the standard-setting and enforcement functions conducted by OSHA. An important area of NIOSH research deals with methods for controlling occupational exposure to potential chemical and physical hazards.

The Engineering and Physical Hazards Branch (EPHB) of the Division of Applied Research and Technology (DART) has been given the lead within NIOSH to study and develop engineering controls, and assess their impact on reducing occupational illness. Since 1976, EPHB (and its predecessor, the Engineering Control Technology Branch) has conducted a large number of studies to evaluate engineering control technology based upon industry, process, or control technique. The objective of each of these studies has been to evaluate and document control techniques and to determine their effectiveness in reducing potential health hazards in an industry or for a specific process.

The goal of this project was to quantify the exposure to crystalline and respirable silica when using a powered saw with aftermarket local exhaust ventilation while cutting concrete roofing tiles. In this case, the local exhaust ventilation consisted of a shroud attached to the cutting section; the shroud was connected to a small electric axial fan through flexible hoses. The dust was then collected in a dust bag for removal. The system was permanently attached to the saw.

\section{OCCUPATIONAL EXPOSURE TO RESPIRABLE CRYSTALLINE SILICA}

Silicosis is an occupational respiratory disease caused by inhaling respirable crystalline silica dust. Silicosis is irreversible, often progressive (even after exposure has ceased), and potentially fatal. Because no effective treatment exists for silicosis, prevention through exposure control is essential. Exposure to respirable crystalline silica dust occurs in many occupations, including construction. Crystalline silica refers to a group of minerals composed of silicon and oxygen; a crystalline structure is one in which the atoms are arranged in a repeating three-dimensional pattern. The three major forms of crystalline silica are quartz, cristobalite, and tridymite. Quartz is the most common form of crystalline silica [Bureau of Mines 1992]. Respirable refers to that portion of airborne crystalline silica that is capable of entering the gas-exchange regions of the lungs if inhaled; this includes particles with aerodynamic diameters less than approximately 10 $\mu \mathrm{m}$ [NIOSH 2002]. 
When proper practices are not followed or controls are not maintained, respirable crystalline silica exposures can exceed the NIOSH Recommended Exposure Limit (REL), the OSHA Permissible Exposure Limit (PEL), or the American Conference of Governmental Industrial Hygienists (ACGIH) Threshold Limit Value (TLV) [NIOSH 2002, ACGIH 2001]. NIOSH recommends an exposure limit of $0.05 \mathrm{mg} / \mathrm{m}^{3}$ to reduce the risk of developing silicosis, lung cancer, and other adverse health effects.

If respirable dust contains more than 1\% silica, the OSHA PEL for respirable dust exposures in general industry can be calculated as shown in the equation below:

$$
\text { Respirable PEL }\left(\mathrm{mg} / \mathrm{m}^{3)}=\frac{10 \mathrm{mg} / \mathrm{m}^{3}}{\% \text { Silica }+2}\right.
$$

where \% silica refers to the percentage of silica by mass contained in an 8-hour sample [29 CFR 1910.1000]. By this equation, the respirable dust PEL is dependent upon the percentage silica contained in the dust. The PEL ranges from $5 \mathrm{mg} / \mathrm{m}^{3}$ if the dust contains no silica, to $0.1 \mathrm{mg} / \mathrm{m}^{3}$ if the dust is $100 \%$ silica.

The current OSHA permissible exposure limit (PEL) for respirable dust containing crystalline silica (quartz) for the construction industry is expressed in millions of particles per cubic foot (mppcf) and is calculated using the following formula [29 CFR 1926.55]:

$$
\text { Respirable PEL }=\frac{250 \text { mppcf }}{\% \text { Silica }+5}
$$

Since the PELs were adopted, the impinger sampling method that was used to evaluate silica exposures in mppcf has been rendered obsolete by gravimetric sampling [OSHA 1996]. OSHA is not aware of any government agencies or employers in this country that are currently using impinger sampling to assess worker exposure to dust containing crystalline silica, and impinger samples are generally recognized as being less reliable than gravimetric samples [OSHA 1996]. OSHA currently instructs its compliance officers to apply a conversion factor of $0.1 \mathrm{mg} / \mathrm{m}^{3}$ per mppcf when converting between gravimetric sampling and particle count standard when characterizing construction operation exposures [OSHA 2001].

The ACGIH ${ }^{\circledR} \mathrm{TLV}^{\circledR}$ s for cristobalite, quartz, and tridymite are all $0.05 \mathrm{mg} / \mathrm{m}^{3}$ [ACGIH 2004]. The ACGIH ${ }^{\circledR}$ has published a notice of their intent to change the $\mathrm{TLV}^{\circledR}$ for $\alpha$-quartz and cristobalite (respirable fraction) to $0.025 \mathrm{mg} / \mathrm{m}^{3}$ and to withdraw the documentation and adopted $\mathrm{TLV}^{\circledR}$ for tridymite [ACGIH 2004]. 


\section{METHODS}

$\underline{\text { Study location }}$

Dust control evaluations were conducted from July 26-28, 2005 at three different construction sites near Denver, CO. All buildings were houses with 2 or more stories. No mechanical general dilution ventilation was present at any of the sites during monitoring.

Construction sites were identified through contacts between NIOSH and the inventor of the engineering control, a roofing contractor. A site was selected if a minimum of 4 hours of activities was established for any set day. A typical sampling day was usually 8 hours of sampling, including 30 minutes for a lunch break. Subject participation was voluntary.

\section{$\underline{\text { Exposure assessment }}$}

Full-shift sampling was conducted to determine the respirable dust and silica exposures of four roofers. Personal breathing zone samples (PBZ) were collected on filter media and using direct reading instruments for real-time sampling. Personal breathing zone samples were collected on $37 \mathrm{~mm}$ diameter PVC filters with a 5 micrometer pore size at a flow rate of 1.7 liters/minute. A $10 \mathrm{~mm}$ nylon cyclone preselector was used to limit the collected particles to respirable sizes.

In order to avoid overloading the filter media, the full shift sampling was split into two samples per worker per shift; one sample was collected during the morning and a second during the afternoon. To allow comparison to OSHA, NIOSH, and ACGIH standards, the results of the morning and afternoon were combined to generate an 8-hour time weighted average (TWA) exposure to respirable dust or respirable silica. The average percent quartz of the two samples was calculated to determine the appropriate OSHA PEL using the following equation:

$$
\text { Percent Quartz }=\frac{\text { Quartz1 }+ \text { Quartz2 }}{\text { Dust } 1+\text { Dust } 2} \times 100
$$

as recommended by OSHA, where Quartz1 and Quartz2 are the mass of quartz in samples 1 and 2, respectively, and Dust 1 and Dust2 are the total mass of respirable dust in samples 1 and 2 respectively [OSHA 1996].

Gravimetric analysis for respirable particulate was carried out with the following modifications to NIOSH Method 0600: 1) the filters and backup pads were stored in an environmentally controlled room $\left(20 \pm 1{ }^{\circ} \mathrm{C}\right.$ and $50 \pm 5 \%$ relative humidity) and were subjected to the room conditions for at least two hours for stabilization prior to tare and gross weighing, and 2) two weighings of the tare weight and gross weight were performed [NIOSH 1994]. The difference between the average gross weight and the average tare weight was the result of the analysis. The limit of detection for this method was $0.02 \mathrm{mg}$. 
Crystalline silica analysis of filter and bulk samples was performed using X-ray diffraction. NIOSH Method 7500 was used with the following modifications: 1) filters were dissolved in tetrahydrofuran rather than being ashed in a furnace; and 2) standards and samples were run concurrently and an external calibration curve was prepared from the integrated intensities rather than using the suggested normalization procedure [NIOSH 1994]. These samples were analyzed for quartz and cristobalite. The limits of detection for quartz and cristobalite on filters were 0.01 and $0.02 \mathrm{mg}$, respectively. The limit of quantitation is $0.03 \mathrm{mg}$ for both quartz and cristobalite. The limits of detection in bulk samples were $0.8 \%$ for quartz and $1 \%$ for cristobalite. The limit of quantitation was $2 \%$ for both forms of crystalline silica in bulk samples.

For the two roofers who were mainly responsible for cutting the tiles, personal breathing zone respirable dust sampling was conducted concurrently using an active sampling portable laser photometer (MIE personal DataRAM model pDR1200, Thermo Electron Corporation, Waltham, MA). The direct reading instruments were zeroed at the beginning of each sampling period according to the manufacturer's recommendations. By fitting the Personal DataRAM (pDR) with a BGI4L metal cyclone (BGI Inc. Waltham, MA) dust pre-selector, the photometer was used to determine the concentration of respirable dust.

Downstream from the photometric sensing stage, a $37 \mathrm{~mm}$ PVC filter with 5 micrometer pore size was also fitted to the photometer and connected via Tygon tubing to a sampling pump calibrated to a flow rate of 2.2 liters/minute to provide simultaneous collection of the analyzed dust. Real-time sampling was stopped during the workers' lunch break to limit the analysis to time spent performing roofing activities. The filter samples from the pDRs were analyzed for respirable dust and for silica using the modified NIOSH analytical methods previously discussed. The results of the PDR filter samples were used to compare real-time and filter-based exposure estimates and to calculate the respirable silica content of the real-time exposures.

The pDRs measured respirable dust concentrations once per second. Because of data storage limitations of the pDRs, the respirable dust concentration readings were averaged over a 5 second interval and logged. The logged data was used to calculate 8-hour TWA respirable dust exposures. The real-time data was also overlayed onto the video recordings of the roofers cutting and laying tiles. This technique, Video Exposure Monitoring (VEM), provided a visual representation of the respirable dust concentration during roofing activities in the form of a bar on the side of the image. The VEM was then used to identify the tasks or work practices that resulted in high exposures to respirable dust.

In order to isolate exposures from the use of the saw, the logged pDR data was also paired with the video recordings of the work shift and used to determine task-based exposure levels. A taskbased TWA exposure was calculated by excluding times that the task was not performed. This process effectively removed potential confounding exposures to provide a better description of the effectiveness of the local exhaust ventilation (LEV) installed on the circular powered saw. 


\section{Description of controls}

This study evaluated the exposures when using an electric Skil ${ }^{\circledR}, 7-1 / 4$ in worm-drive circular saw model hd $77 \mathrm{~m}$ with an aftermarket local exhaust ventilation installed. The local exhaust ventilation consisted of a shroud attached to the cutting plane of the saw; the shroud was then connected to a small electric axial fan (Pneo model $77 \mathrm{mag}$ ), which is intended to collect dust at the point of generation. After passing through the fan, the dust was collected and retained on a cloth bag which also served as a filter media. Periodically, the bag would need to be emptied or replaced as it filled with dust. The bag material was laboratory tested by NIOSH using a characteristic aerosol typically used for testing respirator filter media efficiency. The aerosol size is within the most penetrating size range for respirator filters. When tested, the LEV control bag had penetration values between $55 \%$ and $61 \%$ over a flow rate range of $80-100$ liters/minute.

The fan flow rate was obtained in laboratory trials; by using a flow meter and mass flow sensor installed (Sierra Flo-Box series 900 model 904M flow meter and Sierra model 730-N5-1 sensor, Sierra Instruments Inc., Monterey, CA) at the outlet of the fan (with the collection bag removed) following a 1-1/2 to 2 -in flexible coupling and a 2 -ft length of 2 -in diameter pipe. The connection between the fan outlet and flexible coupling was wrapped in parafilm to make an airtight seal. The fan was capable of pulling an average flow rate of 1056 liters/minute or 37.3 cubic feet per minute (cfm), with the saw on, no blade and no load on the system. When an attempt was made to repeat this measurement in the field at the end of the work day, dust from the roofing tiles in the air stream prohibited its completion.

The system was activated automatically when the trigger switch on the saw was depressed, and shut down when the trigger was released. The local exhaust ventilation was installed as a permanent attachment which added to the weight of the tool, possibly compromising the manufacturer's design specifications. In addition, the installation of the dust collector required the saw to be used by the worker pulling the saw toward themself, necessitating the removal of the blade guard.

\section{$\underline{\text { Wind and weather measurements }}$}

Wind direction and velocity were measured using an ultrasonic wind sensor (WindObserver II, Gill Instruments Ltd., Lymington, England) mounted on a low wooden stand and placed on top of a stack of stored construction material. 


\section{RESULTS AND DISCUSSION}

A total of thirty-five samples were collected at three different sampling locations over a three day period. During the installation of the concrete roofing tiles, employees cut the tiles to accommodate the shape of the roof structure (e.g., peaks, hips and valleys). Employees used an electric Skil $^{\circledR}$ saw with the aftermarket LEV control installed to cut the tiles. During cutting activities, exposures to respirable crystalline silica exceeded occupational exposure limits such as the OSHA PEL, NIOSH REL, and ACGIH TLV. The two individuals cutting the tiles had higher levels of exposure than those laying tiles. A leaf blower was used to clean the tiles to prevent staining from water or moisture. This process created a considerable amount, of airborne concrete dust, comparable or even greater than the dust created when cutting the tiles.

\section{$\underline{\text { Respirable crystalline silica and respirable dust exposures }}$}

The results of personal breathing zone (PBZ) samples collected using the filters and cyclones are presented in Tables 2 and 3. Table 2 includes the results from respirable dust samples. The 8hour TWA respirable dust exposures of the workers ranged from $0.13 \mathrm{mg} / \mathrm{m}^{3}$ to $2.70 \mathrm{mg} / \mathrm{m}^{3}$, with an average 8 -hour TWA of $1.26 \mathrm{mg} / \mathrm{m}^{3}$. The 8 -hour TWA respirable dust exposures for the saw operators ranged from $0.58 \mathrm{mg} / \mathrm{m}^{3}$ to $2.62 \mathrm{mg} / \mathrm{m}^{3}$ and an average exposure of $1.56 \mathrm{mg} / \mathrm{m}^{3}$. The tile layers' 8-hour TWA respirable dust exposure average $0.66 \mathrm{mg} / \mathrm{m}^{3}$, but ranged from 0.13 $\mathrm{mg} / \mathrm{m}^{3}$ to $2.70 \mathrm{mg} / \mathrm{m}^{3}$. The respirable dust exposures exceeded the OSHA PEL for almost all saw operators, and this limit was also exceeded for some of the roofers. The fact that not all roofers were overexposed may be due to several factors including wind conditions, silica generation rate, and proximity to the cutter or to the person using the leaf blower. It is important to mention that the leaf blower was operated by any of the workers. There was not a set person to complete this task. In general, exposures to cutters/roofers were higher than for roofers.

Table 3 illustrates the concentrations of silica dust for roofers and cutters/roofers. Respirable silica concentration 8-hour TWA exposures ranged from $0.02 \mathrm{mg} / \mathrm{m}^{3}$ to $0.51 \mathrm{mg} / \mathrm{m}^{3}$, with an average exposure of $0.28 \mathrm{mg} / \mathrm{m}^{3}$. The exposures to cutters/roofers were higher with an average 8-hour TWA quartz exposure of $0.38 \mathrm{mg} / \mathrm{m}^{3}$, compared to an average 8-hour TWA respirable quartz exposure of $0.07 \mathrm{mg} / \mathrm{m}^{3}$ for the tile layers. All PBZ TWA samples for silica but one exceeded the NIOSH/ACGIH criteria.

The 8-hour TWA exposures to respirable dust were compared to the OSHA PELs, and the respirable quartz 8-hour TWA exposures were compared to the NIOSH REL and ACGIH TLV. A summary of the comparisons is shown in Table 4.

The real-time respirable dust data were also used to calculate 8-hour TWA exposures, which ranged from $0.84 \mathrm{mg} / \mathrm{m}^{3}$ to $2.5 \mathrm{mg} / \mathrm{m}^{3}$. The results of the direct reading sampling are summarized in Table 5. 
One hundred percent of the 8-hour TWAs calculated from the direct reading data exceeded exposure limits enforced by OSHA. In general, the TWAs calculated from the direct reading instruments were higher than the corresponding gravimetric sampling results. However, there was no significant difference $(\mathrm{p}=0.4818)$ between the average TWA respirable dust exposures calculated from the gravimetric data and the real-time sampling data.

The video exposure monitoring data indicate that the two main respirable dust exposures occurred during tile cutting and tile cleaning tasks. The respirable dust exposure during cutting ranged from $6.04 \mathrm{mg} / \mathrm{m}^{3}$ to $17.40 \mathrm{mg} / \mathrm{m}^{3}$ with a TWA exposure of $11.95 \mathrm{mg} / \mathrm{m}^{3}$. Each cut was approximately 10 to 20 seconds in duration. On average, cutting tasks accounted for approximately 60 minutes $(12.5 \%)$ of a full, 8-hour work shift. Respirable dust exposures while cleaning the tiles with the leaf blower ranged from $2.16 \mathrm{mg} / \mathrm{m}^{3}$ to $5.38 \mathrm{mg} / \mathrm{m}^{3}$. The TWA respirable dust exposure during cleaning was $3.44 \mathrm{mg} / \mathrm{m}^{3}$. On average, the two saw operators spent 10 minutes using the leaf blower each shift. The mean respirable dust TWA exposures were significantly higher during cutting than during tile cleaning and were significantly higher than the overall TWA respirable dust exposure. Table 6 presents a summary of task-based respirable dust results from real-time monitoring.

The video exposure monitoring images displayed more visible dust during tile cleaning than tile cutting, but the real-time monitoring indicated that higher respirable dust concentrations were observed during tile cutting. These results suggest that most of the dust re-aerosolized by the blower is above the respirable size range.

The control technology examined in this report was evaluated previously at other roofing sites by OSHA (on two occasions), Pinnacol Assurance and Colorado State University (CSU). The results of the personal exposure monitoring performed during these evaluations are reported in Table 7. The OSHA investigations found that the exposure of one of the three employees sampled exceeded the OSHA PEL for silica in construction. Two of the OSHA-measured exposures exceeded the NIOSH REL and ACGIH TLV for crystalline silica as an 8-hr TWA. Neither OSHA report describes the amount of time the employees spent cutting tiles. The OSHA report of the July 31, 2001 investigation does note that the sampling train used to evaluate the employee sampled for 446 minutes was disconnected from the sampling pump for about and hour and fifteen minutes, so the reported results may underestimate that employee's exposure. The other employee evaluated on that occasion was reported by OSHA to have cut more tiles. Pinnacol Assurance reported that neither of the roofers' exposures they evaluated exceeded the OSHA PEL, but one employee's silica exposure did exceed the ACGIH TLV (and NIOSH REL). The Pinnacol Assurance report does not provide any information on work practices, such as the amount of time spent cutting tiles. The evaluation by CSU found that neither of the two employees evaluated were exposed to silica in excess of the OSHA PEL. However, one of their exposures was slightly in excess of the NOISH REL and one was slightly below. The CSU report notes that cutting tile was estimated to represent less than $25 \%$ of the roofers' activities. One explanation for the differences among these results and between these results and the 
NIOSH evaluation is that the amount of time spent cutting tile (or using the leaf blower) varied from job to job.

\section{Bulk crystalline silica sampling results}

Analysis of the bulk samples collected from three of the sampling locations indicated that they contained between $19 \%$ and $26 \%$ quartz (by weight). This variability may depend on whether the sample contained more aggregate.

$\underline{\text { Wind and weather results }}$

On Day one, the average wind speed was $5.03 \mathrm{mph}$. The prevailing wind was from the southwest (average bearing 241 degrees). On Day two, the average wind speed was $3.29 \mathrm{mph}$. The prevailing wind was from the southeast (average bearing 164 degrees). On Day three, the average wind speed was $4.92 \mathrm{mph}$. The prevailing wind was from the southwest (average bearing 184 degrees). The workers' positions in relation to the wind direction changed throughout the day, so no attempt was made to correlate wind speed with exposure. However, based on observations of the airborne dust, the wind did not appear to hinder the controls. The temperature ranged from 64 to $83{ }^{\circ} \mathrm{F}$. The relative humidity ranged from 19 to $72 \%$ [Weather Underground 2005]

\section{$\underline{\text { Conclusions and recommendations }}$}

This study demonstrated that exposures to employees cutting concrete roofing tiles exceeded the OSHA PEL and the NIOSH REL. Exposures to employees performing activities other than cutting tiles may exceed the OSHA PEL or NIOSH REL, depending on several factors including weather and wind conditions, proximity to the source, generation rate, and work practices. Therefore, other methods to control respirable dust and silica exposures should be implemented to prevent overexposures.

As mentioned in the results and discussion section, a leaf blower was used to remove dust from the tiles. This process should be carefully reviewed as it creates an unnecessary exposure to all employees, whether they cut or lay the tiles. Researchers recommend investigating the use of alternative means of cleaning the tiles without making particles airborne. The use of manual cutters has proven to reduce exposures below the OSHA PEL and the NIOSH REL. Researchers recommend the further investigation of manual cutters or improved local exhaust ventilation. The results indicate that, in general, workers will need to use respiratory protection when they are using the saw and/or the leaf blower.

Tile cutting activities produced higher TWA concentrations of respirable dust than leaf blowing activities. Therefore, work practice modifications and administrative controls should target these two activities. Work practice modifications could include a greater awareness of positioning 
when cutting tiles; workers should be encouraged to stay upwind of the cutting and cleaning operations whenever possible.

All of the workers were exposed to respirable crystalline silica in excess of the NIOSH REL. While some of the tile layers' exposures to crystalline silica can be attributed to cleaning activities, working in close proximity to tile cutting also contributed to their exposures. At times, both of the tile saws were operating in the same area, providing a dual source of exposure to the roofers. Work practice changes such as distancing the saw operators from each other and from other roofers may also reduce exposures.

Both of the ventilated saw operators were overexposed to respirable dust and respirable silica during each shift observed. All of the roofers, including roofers with mainly tile laying responsibilities, were sometimes overexposed to silica. The use of the tile saw equipped with local exhaust ventilation did not reduce exposures to respirable dust and silica below occupational acceptable levels. The local exhaust ventilation control should be modified to effectively control exposures to dust, or the company should seek other engineering controls proven to reduce exposures below occupational limits. In the meantime, work practice modifications, administrative controls, and a comprehensive respiratory protection program should be implemented in order to control respirable dust and respirable silica exposures. 


\section{REFERENCES}

1. ACGIH [2001]. Threshold limit values for chemical substances. Cincinnati, OH: American Conference of Governmental Industrial Hygienists.

2. ACGIH [2004]. Threshold limit values for chemical substances. Cincinnati, OH: American Conference of Governmental Industrial Hygienists.

3. Bureau of Mines [1992]. Crystalline silica primer. Washington, DC: U.S. Department of the Interior, Bureau of Mines, Branch of Industrial Minerals, Special Publication.

4. Croteau GA, Flanagan ME, Camp JE and Seixas NS [2002]. The Efficacy of Local Exhaust Ventilation for Controlling Dust Exposures During Concrete Surface Grinding. Department of Environmental and Occupational Health and Sciences, University of Washington, Seattle, WA.

5. NIOSH [2002]. NIOSH Hazard Review: Health Effects of Occupational Exposure to Respirable Crystalline Silica. Cincinnati, OH: U.S. Department of Health and Human Services, Public Health Service, Centers for Disease Control and Prevention, National Institute for Occupational Safety and Health, DHHS (NIOSH) Publication No. 2002-129.

6. 29 CFR 1910.1000 [2003]. Code of Federal Regulations. Washington, DC: U.S. Government Printing Office, Office of Federal Register, 2003.

7. 29 CFR 1926.55 [1997]. Code of Federal Regulations. Washington, DC: U.S. Government Printing Office, Office of Federal Register, 1997.

8. NIOSH [1994]. NIOSH manual of analytical methods. 4th rev. ed., Eller PM, ed. Cincinnati, OH: U.S. Department of Health and Human Services, Public Health Service, Centers for Disease Control and Prevention, National Institute for Occupational Safety and Health, DHHS (NIOSH) Publication No. 94-113.

9. OSHA [1996]. Memorandum for regional administrators from: Joseph A. Dear. Subject: Special emphasis program (SEP) for silicosis. May 2, 1996. Appendix F: Permissible Exposure Limits for Construction and Maritime.

10. OSHA [2001]. Memorandum for regional administrators and silica coordinators from: Richard E. Fairfax, Director, Directorate of Compliance Programs. Subject: Transmission of NIOSH recommended conversion factor for silica sample results and favorable appellate court decision on silica sampling. September 4, 2001. 
11. Weather Underground [2005]. History for Denver Centennial, Colorado. World Wide Web $[\mathrm{URL}=$

http://www.wunderground.com/history/airport/KAPA/2005/7/26/DailyHistory.html?req $\underline{\text { city }}=$ NA\&req state $=$ NA\&req_statename $=$ NA ], December 2005. 


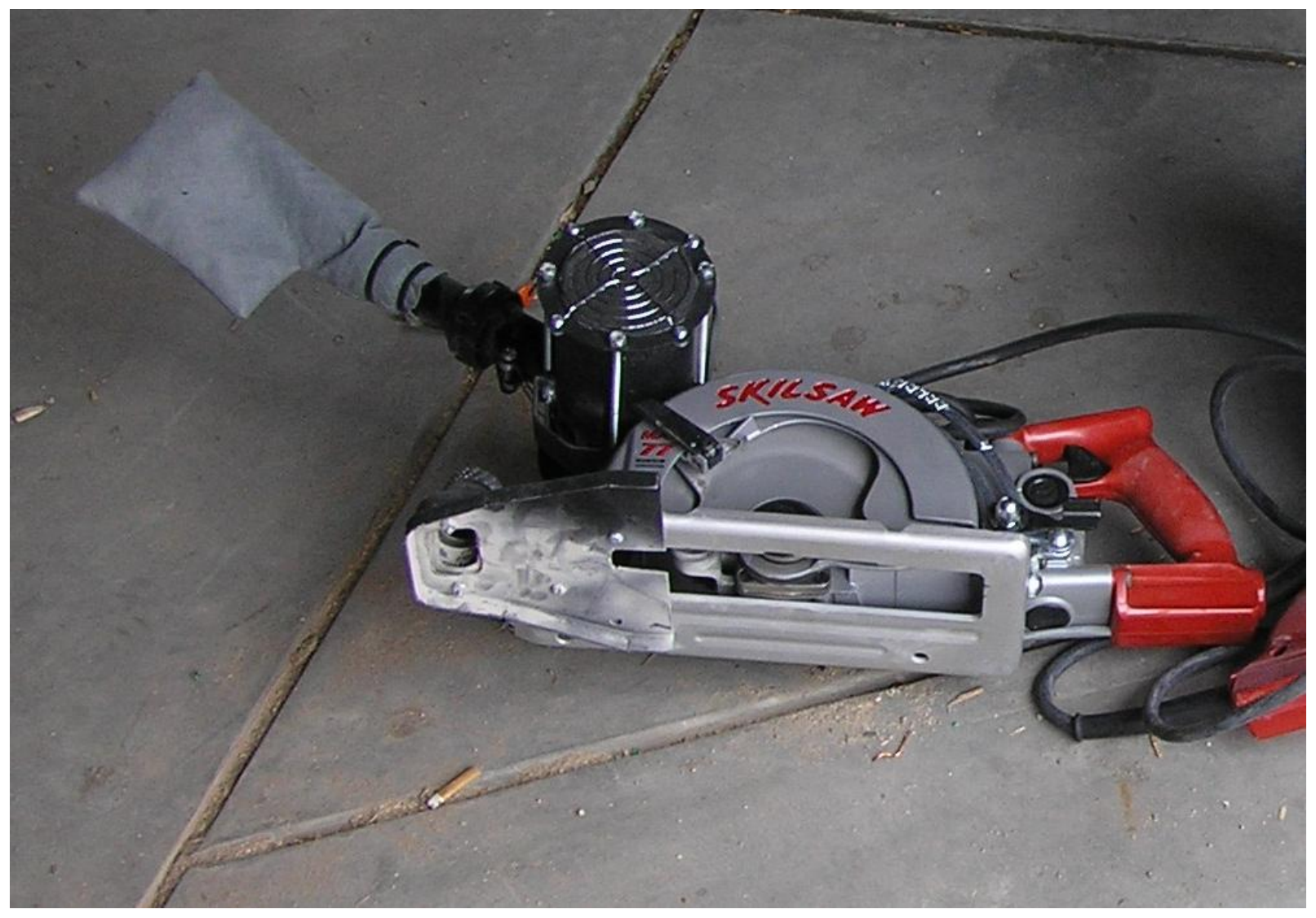

Figure 1. Saw with aftermarket local exhaust ventilation. 


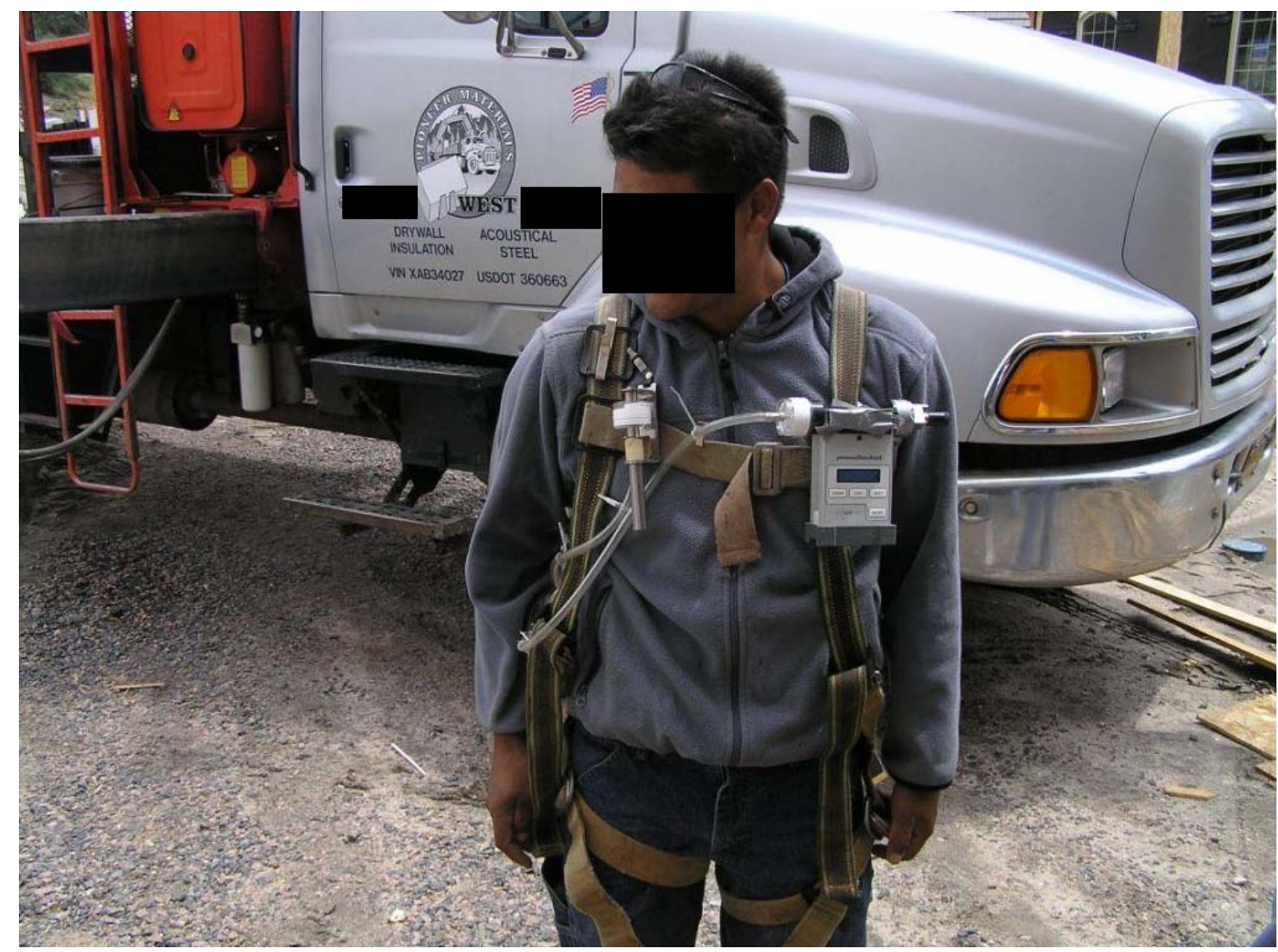

Figure 2. Cutter/Roofer with sampling equipment. 


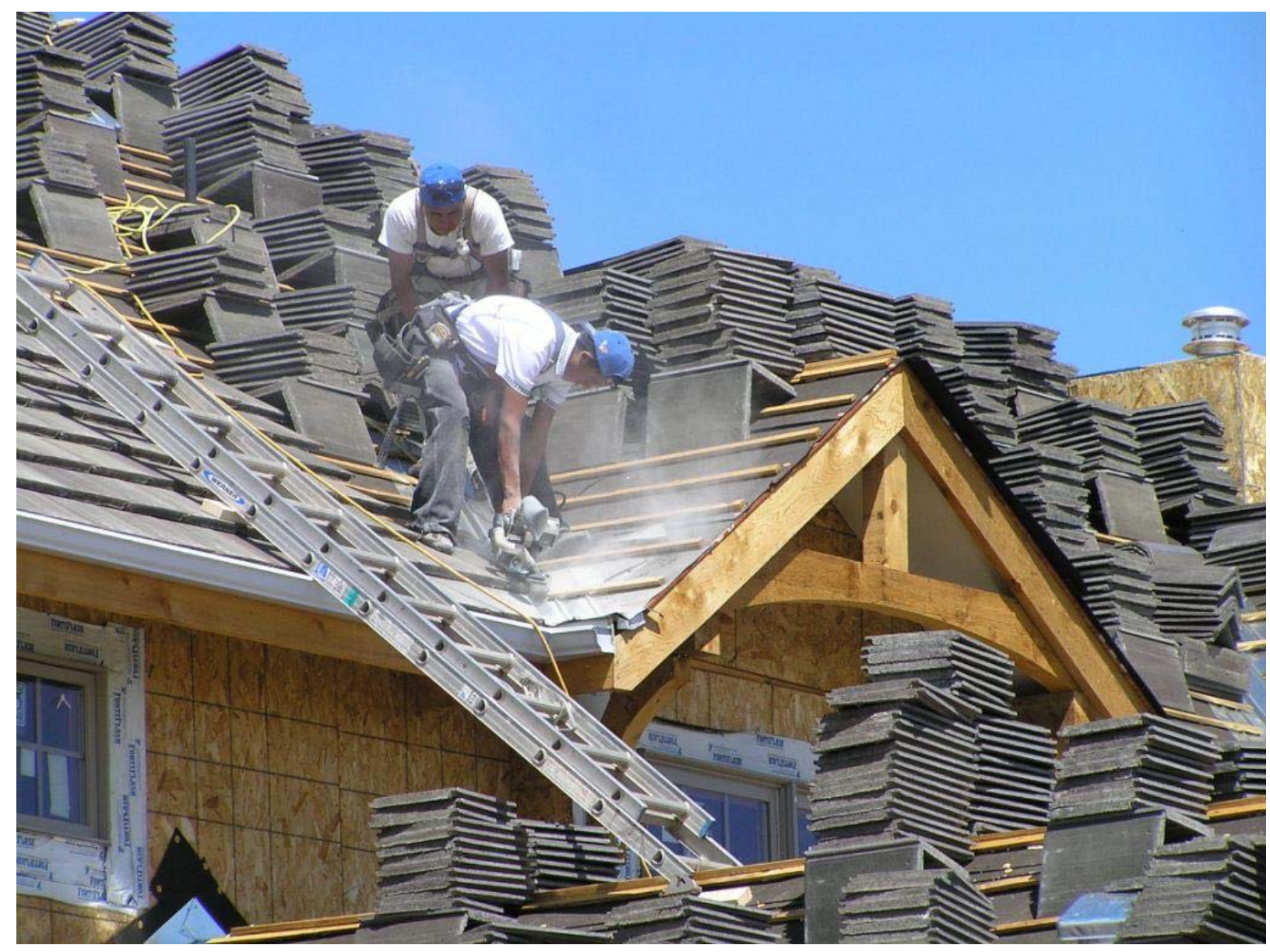

Figure 3. Roof arrangement while installing tiles. 


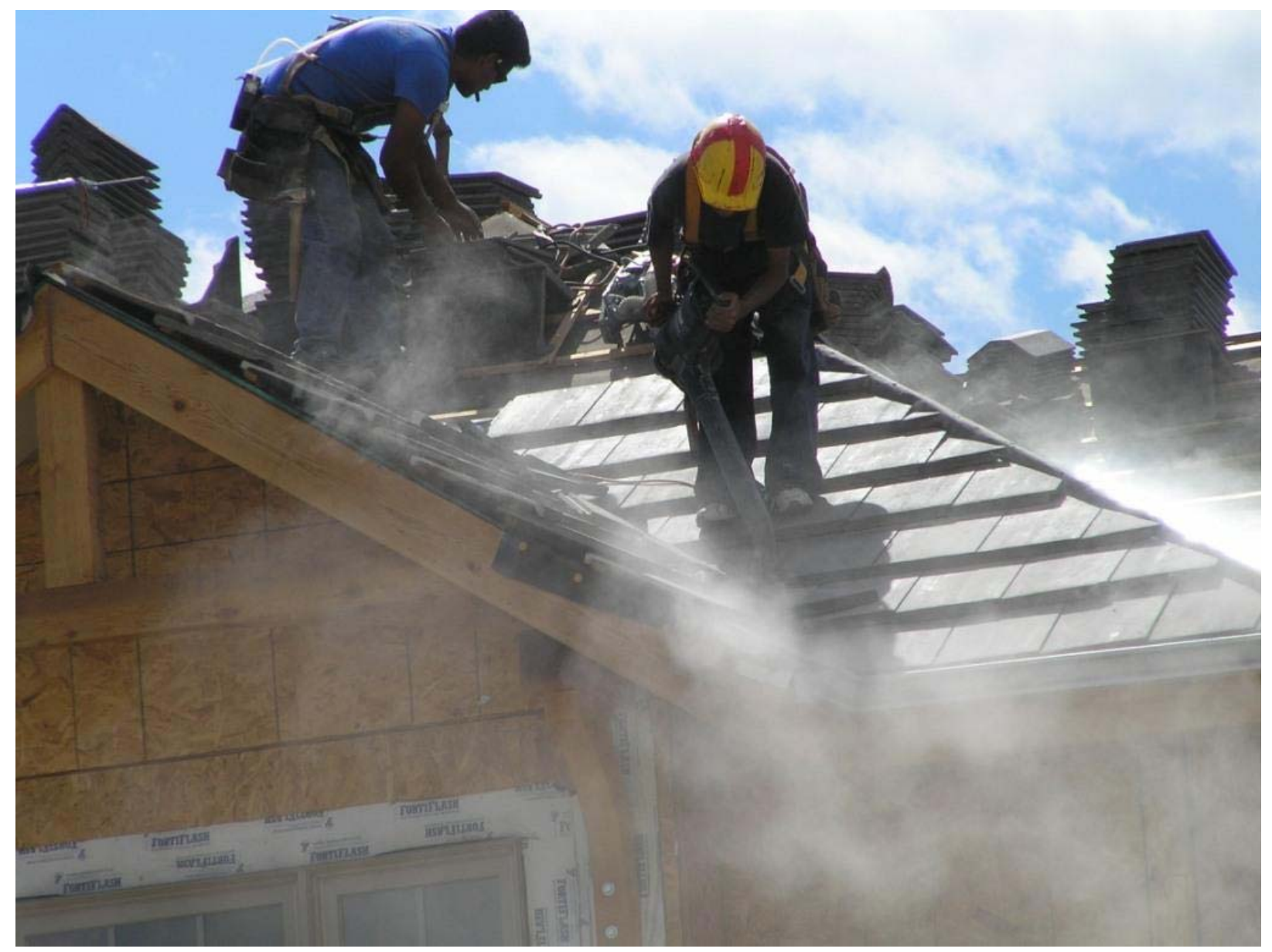

Figure 4. Workers using leaf blower to clean dust from tiles. 


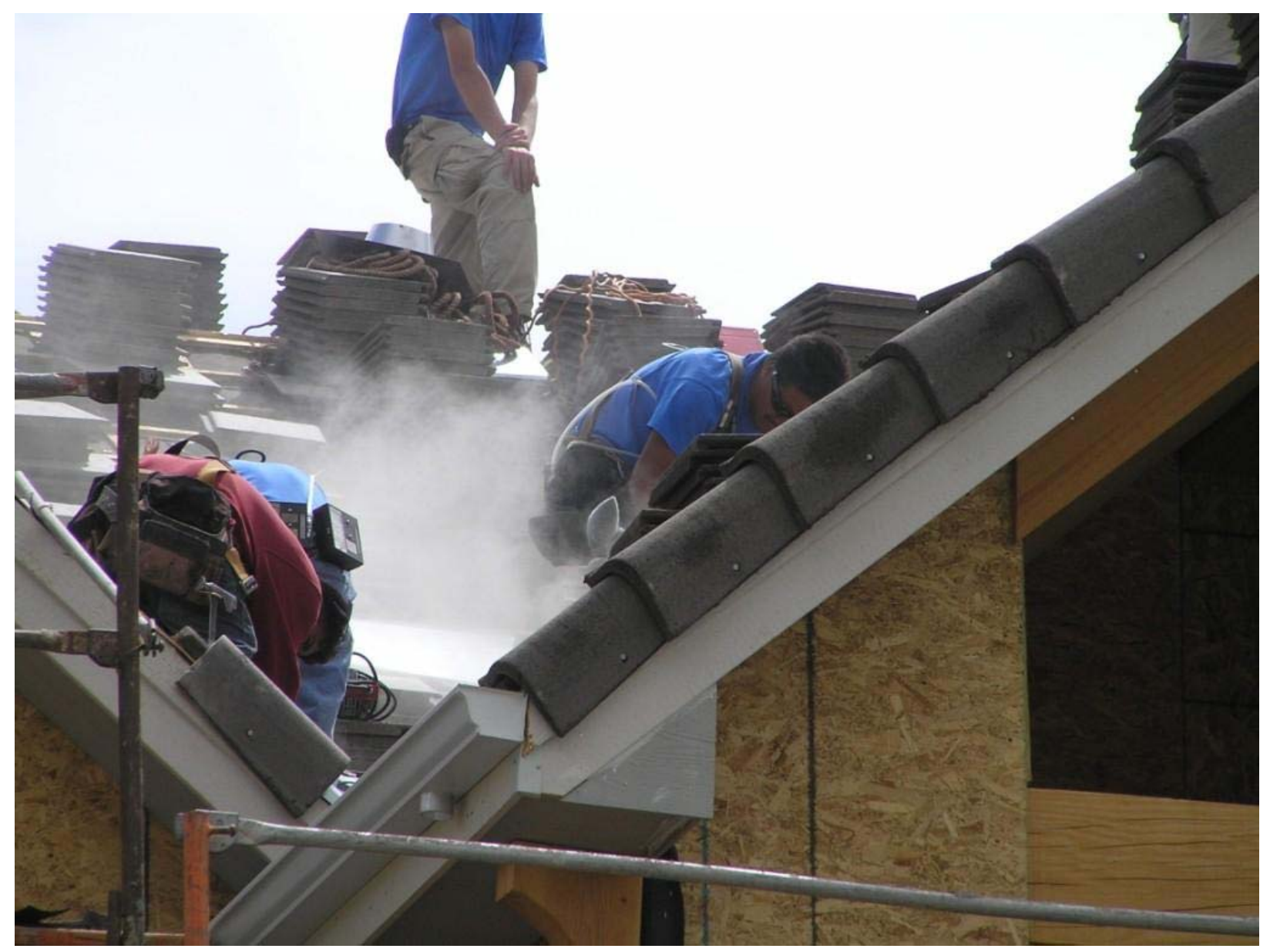

Figure 5. Workers cutting concrete roofing tiles. 
Table 1: Experimental Design

\begin{tabular}{|c|c|c|c|c|c|c|c|}
\hline & \multicolumn{4}{|c|}{ Sample Description } & \multirow[b]{2}{*}{$\begin{array}{l}\text { Average } \\
\text { Flow } \\
\text { (LPH) }\end{array}$} & \multirow[b]{2}{*}{$\begin{array}{c}\text { Sampling } \\
\text { Duration } \\
\text { (min) }\end{array}$} & \multirow[b]{2}{*}{$\begin{array}{c}\text { Sample } \\
\text { Volume } \\
\text { (L) }\end{array}$} \\
\hline & $\begin{array}{l}\text { Sample } \\
\text { Number }\end{array}$ & Date & \begin{tabular}{|l} 
Job \\
Description
\end{tabular} & Worker & & & \\
\hline \multirow{8}{*}{ 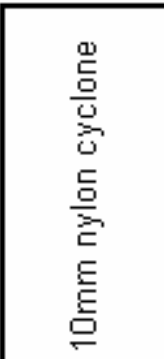 } & B05-464 & $7 / 26 / 2005$ & cutter/roofer & 1 & 1.64 & 174 & 285.19 \\
\hline & BD5-471 & $7 / 26 / 2005$ & cutter/roofer & 1 & 1.64 & 190 & 311.41 \\
\hline & BD5-462 & $7 / 26 / 2005$ & roofer & 3 & 1.66 & 165 & 273.74 \\
\hline & $\mathrm{B} 05-469$ & $7 / 26 / 2005$ & roofer & 3 & 1.66 & 184 & 305.26 \\
\hline & B05-461 & 7/26/2005 & roofer & 4 & 1.67 & 165 & 275.88 \\
\hline & B05-466 & $7 / 26 / 2005$ & roofer & 4 & 1.67 & 187 & 312.66 \\
\hline & $\mathrm{B} 05-463$ & $7 / 26 / 2005$ & cutter/roofer & 2 & 1.70 & 166 & 281.87 \\
\hline & B05-470 & $7 / 26 / 2005$ & cutter/roofer & 2 & 1.70 & 196 & 332.81 \\
\hline \multirow{4}{*}{ 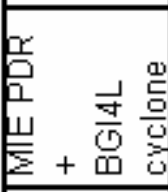 } & B05-491 & 7/26/2005 & cutter/roofer & 4 & 2.12 & 175 & 371.70 \\
\hline & $B 05-494$ & $7 / 26 / 2005$ & cutter/roofer & 4 & 2.12 & 187 & 397.19 \\
\hline & BD5-501 & $7 / 26 / 2005$ & cutter/roofer & 2 & 2.13 & 167 & 356.38 \\
\hline & $\mathrm{B} 05-502$ & $7 / 26 / 2005$ & cutter/roofer & 2 & 2.13 & 73 & 155.78 \\
\hline \multirow{9}{*}{ 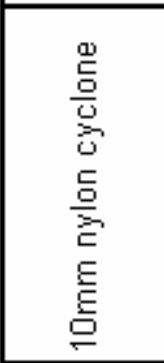 } & & & & & & & \\
\hline & B05-489 & & roofer & 3 & ( & 244 & \\
\hline & B05-293 & $7 / 27 / 2005$ & roofer & 3 & 1.71 & 171 & 291.90 \\
\hline & B05-487 & $7 / 27 / 2005$ & cutter/roofer & 2 & 1.72 & 250 & 429.75 \\
\hline & $\mathrm{B} 05-477$ & $7 / 27 / 2005$ & cutter/roofer & 2 & 1.72 & 162 & 278.48 \\
\hline & B05-479 & $7 / 27 / 2005$ & cutter/roofer & 1 & 1.74 & 248 & 431.52 \\
\hline & B05-292 & $7 / 27 / 2005$ & cutter/roofer & 1 & 1.74 & 162 & 281.88 \\
\hline & BD5-475 & $7 / 27 / 2005$ & roofer & 4 & 1.74 & 243 & 423.31 \\
\hline & BD5-483 & $7 / 27 / 2005$ & roofer & 4 & 1.74 & 168 & 292.66 \\
\hline \multirow{4}{*}{$\begin{array}{l}\frac{y}{2} \\
\text { E } \\
E\end{array}$} & BD5-493 & $7 / 27 / 2005$ & cutter/roofer & 2 & 2.22 & 248 & 549.32 \\
\hline & BD5-495 & $7 / 27 / 2005$ & cutter/roofer & 2 & 2.22 & 16 & 363.26 \\
\hline & B05-504 & $7 / 27 / 2005$ & cutter/roofer & 1 & 2.24 & 250 & 559.50 \\
\hline & B05-499 & $7 / 27 / 2005$ & cutter/roofer & 1 & 2.24 & 161 & 360.32 \\
\hline & & & & & & & \\
\hline \multirow{8}{*}{ 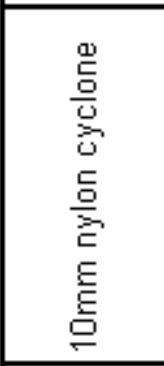 } & B05-481 & $7 / 28 / 2005$ & Cutter/roofer & 2 & 1.70 & 226 & 384.88 \\
\hline & BD5-490 & $7 / 28 / 2005$ & cutter/roofer & 2 & 1.70 & 180 & 306.54 \\
\hline & B05-482 & $7 / 28 / 2005$ & roofer & 4 & 1.71 & 231 & 395.63 \\
\hline & B05-485 & $7 / 28 / 2005$ & roofer & 4 & 1.71 & 186 & 318.56 \\
\hline & BD $05-473$ & $7 / 28 / 2005$ & roofer & 3 & 1.71 & 23 & 395.93 \\
\hline & BD5-488 & $7 / 28 / 2005$ & roofer & 3 & 1.71 & 185 & 317.09 \\
\hline & B05-476 & $7 / 28 / 2005$ & cutter/roofer & 1 & 1.81 & 228 & 412.00 \\
\hline & B05-478 & $7 / 28 / 2005$ & cutter/roofer & 1 & 1.81 & 183 & 403.45 \\
\hline \multirow{4}{*}{ 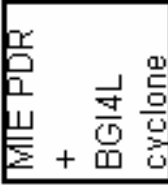 } & B05-505 & $7 / 28 / 2005$ & cutter/roofer & 2 & 2.23 & 181 & 403.45 \\
\hline & $B 05-496$ & $7 / 28 / 2005$ & cutter/roofer & 1 & 2.26 & 228 & 514.37 \\
\hline & B05-509 & $7 / 28 / 2005$ & cutter/roofer & 1 & 2.26 & 182 & 410.59 \\
\hline & $B 05-498$ & & cutter/roofer & 2 & & & Excluded \\
\hline
\end{tabular}

B05-498 Excluded: filter cassette disconnected from respirable dust pre-separator during sampling 
Table 2: Respirable Dust Calculations

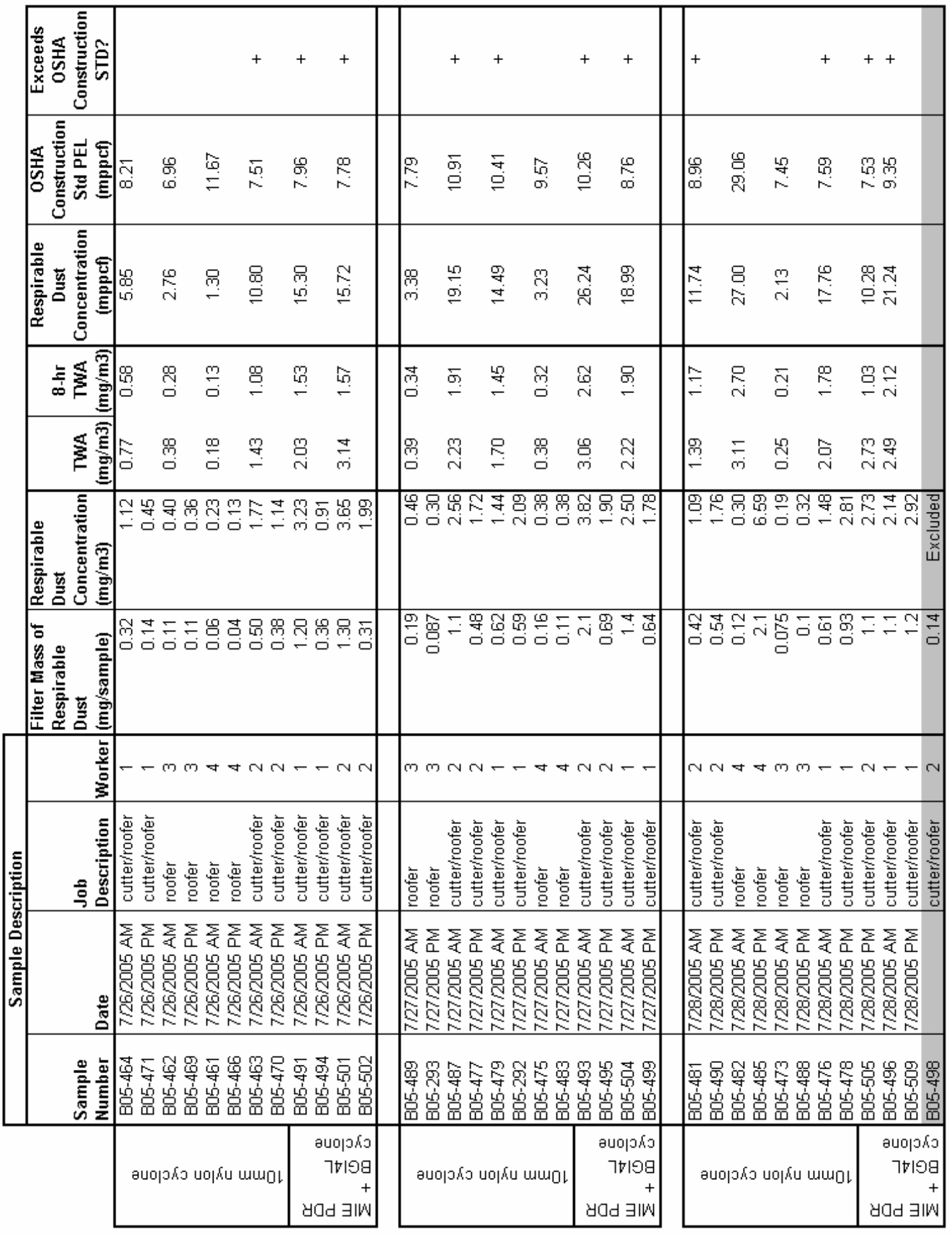

$+=$ Exceeded Criteria 
Table 3: Respirable Silica Calculations

\begin{tabular}{|c|c|c|c|c|c|c|c|c|}
\hline & \multicolumn{3}{|c|}{ Sample Description } & \multirow[b]{2}{*}{$\begin{array}{c}\text { Filter Mass } \\
\text { of Quartz } \\
\text { (mg/sample) }\end{array}$} & \multirow[b]{2}{*}{$\begin{array}{c}\text { Respirable } \\
\text { Quartz } \\
\text { Concentration } \\
\text { (mg } / \mathrm{m} 3 \text { ) }\end{array}$} & \multirow[b]{2}{*}{$\begin{array}{c}\text { TWA } \\
(\mathbf{m g} / \mathbf{m} 3)\end{array}$} & \multirow[b]{2}{*}{$\begin{array}{c}\text { 8-hr } \\
\text { TWA } \\
(\mathbf{m g} / \mathrm{m} 3)\end{array}$} & \multirow[b]{2}{*}{$\begin{array}{c}\text { Exceeds } \\
\text { NIOSH } \\
\text { REL? }\end{array}$} \\
\hline & Date & \begin{tabular}{|l} 
Job \\
Description
\end{tabular} & Worker & & & & & \\
\hline$\stackrel{d}{5}$ & $\begin{array}{l}7 / 26 / 2005 \text { AM } \\
7 / 26 / 2005 \text { PM }\end{array}$ & $\begin{array}{l}\text { cutter/roofer } \\
\text { cutter/roofer }\end{array}$ & $\begin{array}{l}1 \\
1\end{array}$ & $\begin{array}{l}0.08 \\
0.04\end{array}$ & $\begin{array}{l}0.27 \\
0.13\end{array}$ & 0.20 & 0.15 & + \\
\hline$\stackrel{ }{\mathrm{O}}$ & $7 / 26 / 2005 \mathrm{AM}$ & roofer & 3 & 0.04 & 0.14 & 0.12 & 0.09 & + \\
\hline $\mathrm{O}$ & $7 / 26 / 2005 \mathrm{PM}$ & roofer & 3 & 0.03 & 0.10 & & & \\
\hline$\frac{5}{x}$ & $7 / 26 / 2005$ АM & roofer & 4 & 0.01 & 0.04 & 0.02 & 0.01 & \\
\hline$\stackrel{E}{E}$ & $7 / 26 / 2005$ PM & roofer & 4 & ND & & & & \\
\hline E & 7/26/2005 АМ & cutter/roofer & 2 & 0.16 & 0.57 & 0.41 & 0.31 & + \\
\hline & $7 / 26 / 2005$ PM & cutter/roofer & 2 & 0.09 & 0.27 & & & \\
\hline & $7 / 26 / 2005$ AM & cutter/roofer & 1 & 0.32 & 0.86 & 0.54 & 0.40 & + \\
\hline 总 & $7 / 26 / 2005 \mathrm{PM}$ & cutter/roofer & 1 & 0.09 & 0.23 & & & \\
\hline Ш & 7/26/2005 АМ & cutter/roofer & 2 & 0.43 & 1.21 & 0.84 & 0.42 & + \\
\hline $\bar{\Sigma}+\overline{0}$ & $7 / 26 / 2005 \mathrm{PM}$ & cutter/roofer & 2 & ND & & & & \\
\hline & & & & & & & & \\
\hline & 7/27/2005 АM & roofer & 3 & 0.06 & 0.13 & 0.11 & 0.09 & + \\
\hline 岶 & 7/27/2005 PM & roofer & 3 & 0.02 & 0.07 & & & \\
\hline$\stackrel{\overline{0}}{\triangleq}$ & 7/27/2005 AM & cutter/roofer & 2 & 0.20 & 0.47 & 0.40 & 0.34 & + \\
\hline $\mathrm{O}$ & 7/27/2005 PM & cutter/roofer & 2 & 0.08 & 0.30 & & & \\
\hline$\frac{5}{2}$ & $7 / 27 / 2005$ AM & cutter/roofer & 1 & 0.12 & 0.28 & 0.32 & 0.28 & + \\
\hline ᄃ & 7/27/2005 PM & cutter/roofer & 1 & 0.11 & 0.39 & & & \\
\hline$\stackrel{\mathrm{E}}{\mathrm{E}}$ & $7 / 27 / 2005$ АМ & roofer & 4 & 0.04 & 0.09 & 0.08 & 0.07 & + \\
\hline & $7 / 27 / 2005 \mathrm{PM}$ & roofer & 4 & 0.02 & 0.07 & & & \\
\hline & $7 / 27 / 2005$ AM & cutter/roofer & 2 & 0.40 & 0.73 & 0.59 & 0.51 & + \\
\hline$\lrcorner \stackrel{\mathscr{I}}{ᄃ}$ & $7 / 27 / 2005 \mathrm{PM}$ & cutter/roofer & 2 & 0.14 & 0.39 & & & \\
\hline ш $\frac{\square}{0}$ & 7/27/2005 АМ & cutter/roofer & 1 & 0.36 & 0.64 & 0.52 & 0.45 & + \\
\hline$\overline{\bar{z}}+\overline{0}$ & $7 / 27 / 2005 \mathrm{PM}$ & cutter/roofer & 1 & 0.12 & 0.33 & & & \\
\hline & & & & & & 032 & 027 & + \\
\hline 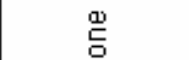 & $7 / 28 / 2005$ PM & cutter/roofer & $\begin{array}{l}2 \\
2\end{array}$ & 0.13 & 0.42 & & & + \\
\hline 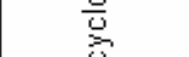 & $7 / 28 / 2005$ AM & roofer & 4 & 0.03 & 0.08 & 0.11 & 0.10 & + \\
\hline $\mathrm{O}$ & 7/28/2005 PM & roofer & 4 & 0.05 & 0.15 & & & \\
\hline$\frac{5}{3}$ & 7/28/2005 АМ & roofer & 3 & 0.03 & 0.08 & 0.07 & 0.06 & + \\
\hline $\bar{E}$ & $7 / 28 / 2005 \mathrm{PM}$ & roofer & 3 & 0.02 & 0.06 & & & \\
\hline$\stackrel{\mathrm{L}}{\mathrm{E}}$ & $7 / 28 / 2005$ АM & cutter/roofer & 1 & 0.13 & 0.32 & 0.51 & 0.43 & + \\
\hline & $7 / 28 / 2005 \mathrm{PM}$ & cutter/roofer & 1 & 0.30 & 0.74 & & & \\
\hline & $7 / 28 / 2005$ PM & cutter/roofer & 2 & 0.31 & 0.77 & 0.60 & 0.51 & + \\
\hline$ـ \stackrel{\mathscr{D}}{\mathrm{C}}$ & $7 / 28 / 2005$ АМ & cutter/roofer & 1 & 0.24 & 0.47 & 0.54 & 0.46 & + \\
\hline ш 寻 & $7 / 28 / 2005 \mathrm{PM}$ & cutter/roofer & 1 & 0.26 & 0.63 & & & \\
\hline $\bar{\Sigma}+\bar{\omega}$ & & cutter/roofer & 2 & $(0.02)$ & & & & \\
\hline
\end{tabular}

\section{$+=$ Exceeded Criteria}


Table 4: Comparison of 8-hour TWA Exposures to Standards

\begin{tabular}{l|c|c|c|c|} 
& $\begin{array}{c}\text { Total Number } \\
\text { of } \\
\text { G-hour TWA } \\
\text { Exposures }\end{array}$ & $\begin{array}{c}\text { Exceeded NIOSH } \\
\text { REL/ ACGIH } \\
\text { TLV for } \\
\text { Respirable Quartz } \\
\text { Number (\%) }\end{array}$ & $\begin{array}{c}\text { Exceeded OSHA } \\
\text { General Industry } \\
\text { Respirable Dust } \\
\text { PEL } \\
\text { Number (\%) }\end{array}$ & $\begin{array}{c}\text { Exceeded OSHA } \\
\text { Construction } \\
\text { Industry Respirable } \\
\text { Dust PEL } \\
\text { Number (\%) }\end{array}$ \\
\hline Roofers & 6 & $5(83 \%)$ & $1(17 \%)$ & $0(0 \%)$ \\
Cutters/Roofers & 12 & $12(100 \%)$ & $12(100 \%)$ & $11(92 \%)$ \\
All Roofers & 18 & $17(94 \%)$ & $13(72 \%)$ & $11(61 \%)$
\end{tabular}

Table 5: 8-hour TWA Respirable Dust Exposure Calculated from Direct Reading Data

\begin{tabular}{c|c|c|c|}
$\begin{array}{c}\text { Saw } \\
\text { Operator }\end{array}$ & Date & $\begin{array}{c}\text { Elapsed Time } \\
(\mathbf{m i n})\end{array}$ & $\begin{array}{c}\text { 8-hour TWA } \\
\text { Respirable Dust Exposure } \\
\left(\mathbf{m g} / \mathbf{m}^{3}\right)\end{array}$ \\
\hline \hline \multirow{3}{*}{1} & $7 / 26 / 05$ & 363 & 1.53 \\
& $7 / 27 / 05$ & 409 & 2.03 \\
& $7 / 28 / 05$ & 483 & 2.21 \\
& & & 1.41 \\
& $7 / 26 / 05$ & 238 & 2.53 \\
& $7 / 27 / 05$ & 414 & $0.84^{\mathrm{a}}$
\end{tabular}

\footnotetext{
${ }^{a}$ The 8-hour TWA respirable dust exposure for Saw Operator $\# 2$ on 07/28/2005 only includes afternoon sampling data. Due to a pump malfunction, the PDR operated in a passive sampling capacity during the morning collection period. This morning collection period was excluded from the analysis.
} 
Table 6: Summary of Task-Based Respirable Dust Results from Real-Time Monitoring

\begin{tabular}{|c|c|c|c|c|c|}
\hline \multirow[b]{2}{*}{$\begin{array}{c}\text { Saw } \\
\text { Operator }\end{array}$} & \multirow[b]{2}{*}{ Date } & \multicolumn{2}{|c|}{ Tile Cutting } & \multicolumn{2}{|c|}{ Cleaning Tiles with a Blower } \\
\hline & & $\begin{array}{c}\text { Elapsed } \\
\text { Time (min) }\end{array}$ & $\begin{array}{c}\text { TWA } \\
\text { Concentration } \\
\left(\mathrm{mg} / \mathrm{m}^{3}\right)\end{array}$ & $\begin{array}{c}\text { Elapsed } \\
\text { Time (min) }\end{array}$ & $\begin{array}{c}\text { TWA } \\
\text { Concentration } \\
\left(\mathbf{m g} / \mathbf{m}^{3}\right)\end{array}$ \\
\hline \multirow{3}{*}{1} & $7 / 26 / 05$ & 64.7 & 17.40 & 10.7 & 2.24 \\
\hline & $7 / 27 / 05$ & 61.3 & 10.97 & 17.2 & 4.78 \\
\hline & $7 / 28 / 05$ & 73.8 & 6.04 & 10.2 & 2.66 \\
\hline \multirow{3}{*}{2} & $7 / 26 / 05$ & 46.7 & 10.42 & 1.2 & 2.16 \\
\hline & $7 / 27 / 05$ & 58.8 & 14.92 & 9.8 & 5.39 \\
\hline & $7 / 28 / 05$ & 36.7 & 6.88 & 2.4 & 4.92 \\
\hline
\end{tabular}

Table 7: Summary of Previous Saw Evaluations

\begin{tabular}{|c|c|c|c|c|c|c|c|}
\hline Evaluation & Sample Date & $\begin{array}{l}\text { Sampling } \\
\text { time (min) }\end{array}$ & \begin{tabular}{|l|} 
8-hr TWA \\
respirable \\
dust $\left(\mathrm{mg} / \mathrm{m}^{3}\right)$
\end{tabular} & \begin{tabular}{|l|} 
TWA \\
Respirable \\
dust \\
$\left(\mathrm{mg}^{3} \mathrm{~m}^{3}\right)$ \\
\end{tabular} & $\begin{array}{l}\% \text { silica in } \\
\text { sample }\end{array}$ & $\begin{array}{l}\text { 8-hr TWA } \\
\text { crystalline } \\
\text { silica } \\
\left(\mathrm{mg}^{3} / \mathrm{m}^{3}\right) \\
\end{array}$ & $\begin{array}{l}\text { TWA } \\
\text { crystalline } \\
\text { silica } \\
\left(\mathrm{mg}^{3} / \mathrm{m}^{3}\right)\end{array}$ \\
\hline \multirow[t]{3}{*}{ OSHA } & July 31,2001 & 443 & 1.67 & 1.81 & 15 & 0.25 & 0.27 \\
\hline & July 31,2001 & 446 & 0.418 & 0.45 & 16 & 0.063 & 0.068 \\
\hline & April 11,2002 & 339 & 0.25 & 0.35 & 16 & 0.04 & 0.057 \\
\hline \multirow[t]{2}{*}{ Pinnacol Assurance } & May 2,2003 & 235 & 0.087 & 0.18 & 23 & 0.02 & 0.041 \\
\hline & May 2,2003 & 232 & 0.568 & 1.18 & 26 & 0.15 & 0.31 \\
\hline \multirow[t]{2}{*}{ Colorado State University } & July 23, 2003 & 335 & 0.22 & 0.32 & 24 & 0.053 & 0.076 \\
\hline & July 23,2003 & 96 & 0.14 & 0.70 & 33 & 0.046 & 0.23 \\
\hline
\end{tabular}

